\author{
Sergey CHIMSHIT, \\ Liudmila GOLOVKOVA, \\ Ihor GRABOVSKII, \\ Alla YAKYMOVA
}

\title{
CONCEPTUAL PRINCIPLES OF BUDGET DECENTRALIZATION STRATEGY DEVELOPMENT IN UKRAINE
}

\begin{abstract}
The main strategic task of modernizing the system of public administration and territorial structure of power should be the creation of effective local selfgovernment, creating comfortable living conditions for citizens, providing them with high quality and affordable public services. Economically active businesses, a sufficient number of skilled workers, developed industrial and social infrastructure are the basis for successful community development. The society still lacks

(C) Sergey Chimshit, Liudmila Golovkova, Ihor Grabovskii, Alla Yakymova, 2020.

Chimshit Sergey, Doctor of Economic Sciences, Associate Professor, Head of the Department of Finance and Marketing, Prydniprovska State Academy of Civil Engineering and Architecture, Ukraine. ORCID: 0000-0002-0861-2226, Email: chimshit@gmail.com.

Golovkova Liudmila, Doctor of Economic Sciences, Professor, Head of the Department of Finance and Economic Security, Dnipro National University of Railway Transport named after Academician V. Lazaryan, Ukraine. ORCID: 0000-0001-5473-6644, Email: g.liudmila22@gmail.com Grabovskii Ihor, Candidate of Economic Sciences, Associate Professor, Department of Finance and Marketing, Prydniprovska State Academy of Civil Engineering and Architecture, Ukraine. Email: i.grabovskii@pgasa.dp.ua

Yakymova Alla. , Candidate of Economic Sciences, Associate Professor, Department of Finance and Economic Security, Dnipro National University of Railway Transport named after Academician V. Lazaryan, Ukraine. ORCID: 0000-0002-8261-4940, Email: allayakymova@gmail.com.
\end{abstract}


effective financial mechanisms to motivate local governments to the effectiveness of decisions on socio-economic territorial development. Given this, the article analyses the current financial problems of decentralization in Ukraine, the impact of national economic development and budget policy on the financial capabilities of local governments. Conceptual directions and resources for increasing the financial independence of the regions have been identified. It is established that the main result of the budget decentralization reform should be not so much more efficient allocation and redistribution of community financial resources, as greater interest and capacity of local governments to increase local budget revenues, find reserves, and improve the efficiency of tax administration and fees. Local self-governments must make decisions based on the following cause-andeffect relationship: the availability of sufficient resources in local budgets is a consequence of the level of economic activity in the region.

\section{Key words:}

Budgetary policy; GDP; decentralization; strategy; local authorities; community; local budgets; financial leverage; problems.

JEL: E440, E690, H610, H710 (770).

\section{Topicality of the research topic}

Indicators of local budgets (structure and dynamics of revenues, expenditures) reflect the general state of socio-economic development of the territory, its potential. The availability of sufficient resources in local budgets is a guarantee that the territorial community has the opportunity to provide better and more diverse services to its residents, implement social and infrastructure projects, create conditions for business development, attract investment capital, develop local development programmes and finance other measures to comprehensively improve the living conditions of community residents.

It has been historically proven that the state is not an efficient economic entity on its own. Due to certain subjective and objective reasons, it does not use the available financial resources in the most optimal way. The centralized state is probably the least effective entity. Therefore, even in the states with a unitary system (which Ukraine is as per the Constitution), the management of financial 
resources is carried out at the lowest levels of public administration. It is important to note that the state system itself can in no way be considered an absolute marker of the effectiveness of the mechanism of public administration. At one time, the USSR was essentially a federal union, but at the same time had an extremely high degree of centralization of public administration and distribution of financial resources. There are many countries in the world that are decentralized (USA, Germany, Canada, Australia, etc.) and have reached a high level of economic development. At the same time, there are many states with a unitary system (Great Britain, France, Japan, Norway, the Netherlands, South Korea, etc.), whose efficiency of the state mechanisms is also very high.

It should be noted that unitary means: «united, one that forms a single whole» (from the French - «unitaire» or from Latin - «unitas»). It is known that there are three types of unitary systems. First, a centralized unitary state that is characterized by the fact that management at all subnational (lower national) territorial levels is carried out by the administration appointed by the highest executive body. Second, a decentralized unitary state that is characterized by the fact that local authorities are formed independently of central authorities (elected by the population, etc.) and are awarded significant autonomy in addressing local issues. Third, a relatively decentralized unitary state that is characterized by a combination of direct local government with local self-government: at the highest (oblast) and middle (rayon) subnational territorial levels, executive bodies of general competence and local self-government bodies function simultaneously.

Until 2014, there was an economic and legal paradox in Ukraine. On the one hand, according to the Constitution of Ukraine, there are local authorities (Councils), elected by the population and formed independently of the central authorities, enjoying certain powers in resolving local issues. On the other hand, there are Administrations appointed by the highest executive body. Meanwhile, the vast majority of financial flows were centralized and returned to localities through budget transfers, but since they returned through administrations, the latter were the ones with influence over them.

Ukraine's decentralization process began in 2014 with the adoption of the Concept of Reforming Local Self-Government and Territorial Structure of Power in Ukraine (Order of the Cabinet of Ministers of Ukraine No. 333-p, 2017), Laws of Ukraine «On Voluntary Amalgamation of Territorial Communities» (Law of Ukraine No. 157-VIII, 2015), «On Cooperation of Territorial Communities» (Law of Ukraine No. 1508-VII, 2014), as well as changes to the Budget and Tax Codes of Ukraine (Law of Ukraine No. 2456-VI, 2010; Law of Ukraine No. 2755-VI, 2010) that concern financial decentralization. This process made it possible to form the institution of local self-government at the base level - amalgamated territorial communities (hereinafter - ATCs) - in accordance with the provisions of the European Charter of Local Self-Government. In particular, it was noted «... The system of local selfgovernment today does not meet the needs of the society. The operation of local self-governments in most local communities does not create and maintain a fa- 

Strategy Development in Ukraine

vourable living environment necessary for comprehensive human development, self-realization, protection of human rights, provision of high quality and affordable administrative, social and other services (hereinafter - public services) by institutions and organizations within the territories...». As a result, Ukraine has a large imbalance in territorial development. On the one hand, there are Kyiv, Poltava and Dnipropetrovsk region, on the other hand, there are such regions as Chernivtsi, Ternopil, Zakarpattia. The ratio of gross regional product per capita of, for example, Poltava region in relation to Chernivtsi region is 3.37 times. The ratio of Kyiv to Chernivtsi region is even higher -7.57 times. Such an imbalance gives rise to other destructive processes. The population is trying to leave the countryside, migrate to medium and large cities (often regional centres), or leave the country. According to the State Statistics Service, 426 rural settlements disappeared from the map of Ukraine from 1990 to 2018. However, the real number of «extinct» villages is much larger: in 2014, 369 uninhabited villages were simply not removed from the state register (Institute of Demography and Social Research of NASU, 2017). Another 4,884 villages are on the verge of extinction, with less than 50 people living in each. At the same time, the birth rate exceeds the death rate only in Kyiv. In 7 regions of Ukraine, the number of children born is not even half of the deceased persons in the same period. According to research, the main factor in the growth of birth rates in Ukraine is the growth of real incomes. In turn, the growth of household income is a consequence of the growth of the country's GDP in general and gross regional product in particular.

\section{Problem statement}

Given that the main task of state economic and financial policy - growth of GDP per capita - is not being fulfilled in Ukraine, radical reform is urgently needed. The territorial structure of power also needs to be improved in order to increase the efficiency of social development management in the respective territory.

Persistent disproportion of the administrative-territorial system is the basis for the existence of an irrational territorial structure of power, which leads to a conflict of competences both between different local self-governments and between local self-governments and local executive bodies. Structural reform should be aimed at achieving a sustainable economic effect provided that the priorities and stages of these reforms are harmonized with the reform of local self-government and territorial structure of power.

New requirements and their influence on formation and realization of the balanced and effective, instead of declarative, budgetary policy require research. The scientific task is to study the key problems of the national economy of Ukraine, taking into account regional characteristics, and their impact on the effectiveness of fiscal policy. 


\section{Analysis of recent research and publications}

The scientific works of famous scientists J. M. Keynes, J. Schumpeter, J. Buchanan are devoted to the development of the theory, methodology and mechanisms of economic, fiscal policy and economic growth. Existing problems in fiscal policy as a socio-economic category were studied by scientists such as O. Vasylyk (2002), V. Demianyshyn (2001), M. Yermoshenko, I. Lunina (2006), S. Mochernyi (2005), Ts. Ohon (2006), V. Oparin (2005), I. Chuhunov (2010), S. Yuriy (2001), F. Yaroshenko (2011). The peculiarities of assessing the quality and state of fiscal policy were researched by such scholars as O. Hordei (2018), I. Lyutyy (2009), S. Yuriy (2001), F. Pikhotskyi (2018) and others.

Despite significant scientific achievements and theoretical accomplishments, a number of topical issues still require in-depth research, development and improvement, especially in the context of globalization.

Aim of the article is to highlight the financial problems of decentralization in Ukraine; identify the impact of national economic development and budget policy on the financial capabilities of local self-governments, as well as to develop and substantiate conceptual areas and reserves of increasing the financial independence of the regions of Ukraine.

The research methods used to achieve the aim include the structural method, comparative analysis of empirical data, and abstract-logical generalization.

\section{Main findings}

The purpose of the budget decentralization reform is to determine the directions, mechanisms and deadlines for the formation of effective local selfgovernment and territorial structure of power. This is done to create and maintain a satisfactory living environment for citizens, provide high quality and affordable public services, establish institutions of direct democracy, meet the interests of citizens in all spheres of life within the territory, harmonizing the interests of the 

Strategy Development in Ukraine

state and local communities. The reform is aimed at changing the scope of responsibility that is delegated to local self-governments and providing appropriate financial instruments. Effective local self-government and the gradual socioeconomic development of the respective territories that it ensures must be accompanied by an increase in the resource and financial base. Decentralization of powers and increase of responsibility, first, should be provided with adequate financial resources. Therefore, in 2014, appropriate amendments were made to the Tax and Budget Codes. Local authorities have received more financial resources to increase economic capacity.

The Concept of Reforming Local Self-Government and Territorial Structure of Power in Ukraine (Order of the Cabinet of Ministers of Ukraine No. 333-p, 2014 ) identified issues that need to be addressed as a matter of priority. In particular, it is noted that since 1991 the number of rural population has decreased by 2.5 million people, while the number of rural settlements - by 348 units (as of April 1, 2014). At the same time, the number of village councils increased by 1,067 units. There are about 12 thousand territorial communities in Ukraine. In more than 6 thousand communities the population is less than 3 thousand people, of which 4809 communities number less than 1 thousand people, and 1129 communities - less than 500 people. The executive bodies of the respective village councils have not been formed in most of them; there are no budgetary institutions, communal enterprises, etc. The local self-government bodies of such communities are practically unable to exercise the powers granted to them by law.

5,419 local governments have budgets 70 percent of which are made up by subsides, 483 territorial communities are maintained at the expense of the state budget by 90 percent. Continuous financial support through the district budgets of small territorial communities uses the system of equalization subsidies, is burdensome for the state budget, and hinders the development of cities and towns.

The Concept of Reforming Local Self-Government and Territorial Structure of Power in Ukraine also clearly defines the new division of powers between local self-governments and executive authorities, as well as the stages of implementation of the Concept and expected results.

However, this Concept does not take into account the basic postulates of public finance and the overall financial system of the country, therefore its implementation has very significant limitations. It can be argued that the purpose, tasks, ways and means of solving problems are incorrectly defined from the outset. As a result, the expected results identify many aspects that defocus reforms and distract from the main goal. In our opinion, the main and only expected result of such a reform should be to stimulate the socio-economic development of territories and stabilize demographic and social processes. Such an approach significantly changes the focus and direction of the reform. Everything else is either secondary or should be seen as a means to an end. The developers of the Con- 
cept made one of the most significant mistakes in management - confused the goal and means to achieve this goal.

It is also important to note that such an important document as this Concept (Order of the Cabinet of Ministers of Ukraine No. 333-p, 2014) was developed and approved only by the Cabinet of Ministers of Ukraine and does not have the status of the Law of Ukraine. This document provides for systemic, complex transformations in the state system, changes in the country's financial system while it does not even have the status of a Code or even a law. All the while, the Concept itself envisages such principles as the rule of law, openness, transparency and public participation.

Let us consider this problem in more detail. It is necessary to determine how the country's budget is formed as a whole and how the budget system in Ukraine is built.

First of all, it should be noted that the state as an actor in socio-economic processes and an element of the state financial system does not create anything by itself. With certain exceptions, it does not generate added value in the economy. It is excluded from the stage of primary income generation of economic entities. The state participates in the movement of financial flows in the economy only in the second stage - the redistribution of financial resources. It forcibly collects payments from all entities, which in theory are classified as either tax or non-tax, but in reality are a mandatory payment on a unilateral basis, and therefore a tax. Its formal name (tax, fee, contribution) has no meaning in this context. An individual or legal entity is forced to give a share of its income to the state without receiving anything in return. From these resources, the state forms certain funds to perform its functions under the law. As such relations of the state with economic entities should be legislated, the Tax Code is Ukraine's main legal basis for them (Law of Ukraine No. 2755-VI, 2010).

An important provision is that the state does not create added value, has no primary income; it only takes a part of it from those who actually have it and create it in the amount that is predetermined and legally established as a fixed percentage. If an economic entity creates less added value, the state automatically receives less funds (if it does not change the rules of the game), and vice versa. If the economic entity does not create anything at all, then there is nothing to redistribute and the state does not receive anything. In the theory and practice of finance, there is a concept of fiscal interest - a share of GDP that the state collects in the form of taxes and redistributes. In other words, it is the level of tax burden in the economy or the level of economic centralization. Thus, we can conclude that the source of filling the state budget of any country is GDP. Hence, if the state wants to increase its own revenues, it has two ways: to increase the fiscal interest rate or stimulate GDP growth.

The first direction in accordance with the law on the optimal level of Laffer tax burden does not have even medium-term prospects. This can only be a one- 
time action to solve a narrow range of problems with the subsequent rollback to the previous level of tax pressure.

It is possible to increase the state budget revenues through borrowings (external or internal), but this path is even more wrong.

Thus, we come to the conclusion that the growth of state budget revenues can occur only if GDP also grows in the country, which is inevitable in the medium and long term. 11 years.

Understanding this, let us consider the situation in Ukraine over the past

Table 1

Ukraine's GDP from 2007 to 2018

\begin{tabular}{|c|c|c|c|c|}
\hline Year & $\begin{array}{c}\text { Nominal GDP in } \\
\text { million UAH }\end{array}$ & Inflation index & $\begin{array}{c}\text { GDP } \\
\text { in million USD }\end{array}$ & $\begin{array}{c}\text { Weighted } \\
\text { average rate }\end{array}$ \\
\hline 2007 & 720731 & 116,6 & 142719 & 5,1 \\
\hline 2008 & 948056 & 122,3 & 179992 & 5,3 \\
\hline 2009 & 913345 & 112,3 & 117228 & 7,8 \\
\hline 2010 & 1082569 & 119,1 & 136419 & 7,9 \\
\hline 2011 & 1316600 & 114,6 & 163160 & 8,1 \\
\hline 2012 & 1408889 & 98 & 175781 & 8,0 \\
\hline 2013 & 1454931 & 100,5 & 183310 & 7,9 \\
\hline 2014 & 1566728 & 124,9 & 131805 & 11,9 \\
\hline 2015 & 1979458 & 143,3 & 90615 & 21,8 \\
\hline 2016 & 2383182 & 112,4 & 93270 & 25,6 \\
\hline 2017 & 2982920 & 113,7 & 112154 & 26,6 \\
\hline 2018 & 3558706 & 109,8 & 129407 & 27,5 * \\
\hline
\end{tabular}

Source: compiled by the author based on the data of State Statistics Service of Ukraine and National Bank of Ukraine

* - official data has not yet been provided, the weighted average exchange rate was calculated based on trading on the currency exchange from the NBU

Table 1 clearly shows that from 2007 to 2018 , the real GDP of Ukraine, expressed in one of the world's reserve currencies (US dollar) has not increased. While nominally in hryvnia equivalent, it has grown exponentially, total inflation in the last 5 years alone amounts to $252 \%$, so Ukraine's real GDP in 2018 has only reached the value of the 2009 crisis and is still far from 2007. 
Figure 1

Nominal and real GDP (adjusted for inflation) of Ukraine from 2007 to 2018

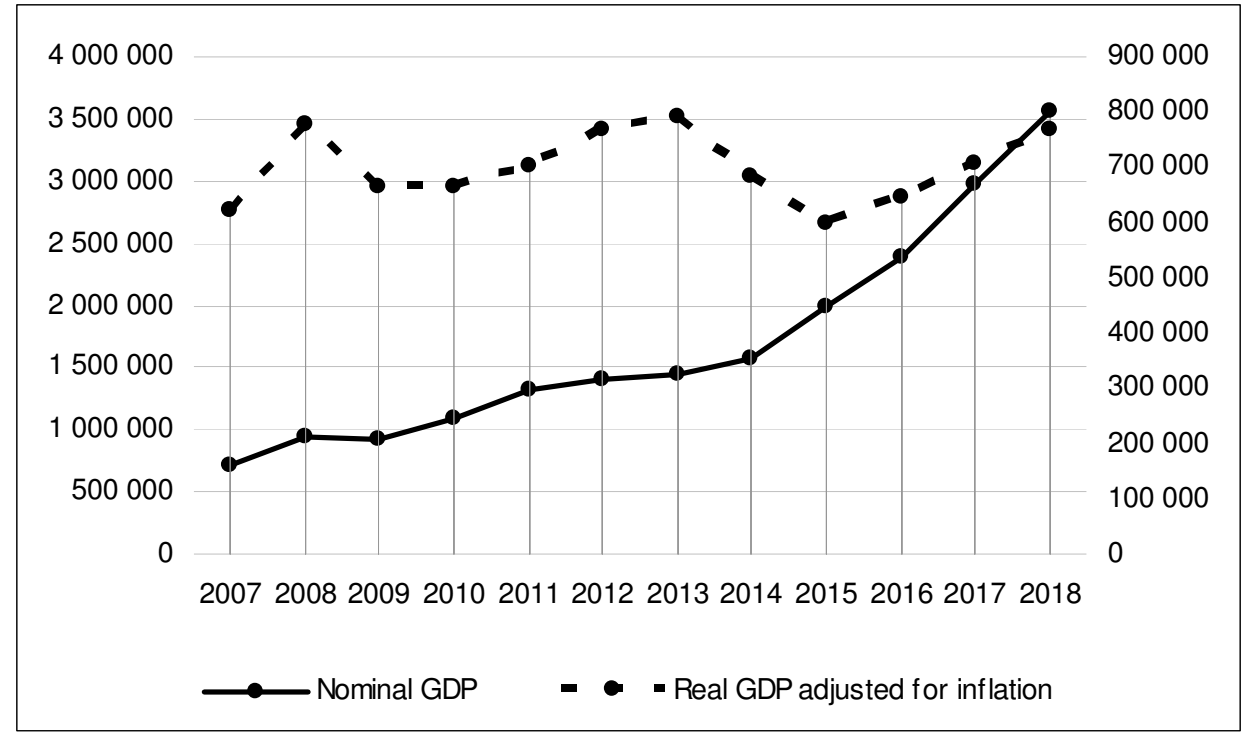

Source: created by the author based on the data of State Statistics Service of Ukraine and National Bank of Ukraine

If the calculations are made in hryvnia, taking into account inflation, the indicators will be slightly different, but the general trend will continue (Fig. 1). The reason for this is the method used for calculating the inflation rate in Ukraine and the correspondence of the current exchange rate of the national currency to its purchasing power and the real exchange rate. However, this problem needs to be considered separately. For now, we will take this into account and will continue to make the calculations of real revenues of the state budget relate to these two indicators.

In general, over the past 11 years, nominal GDP has grown 4.93 times, but the national currency fell 5.45 times and aggregate inflation was $464 \%$. Such a difference in the growth rate of nominal GDP and the national currency indicates a significant inflationary potential in conditions when the financial and economic system of Ukraine is open and more than $50 \%$ of GDP is formed by external operations. 
Hence, we can conclude that the real GDP of Ukraine has not increased over the past 11 years, so the basis for the formation of state budget revenues has not increased. In principle, there is no more real money.

Let us analyse the dynamics of revenues of the State Budget of Ukraine.

First, it is necessary to define certain terminological features. In accordance with the Budget Code, the budget of Ukraine is divided into "State Budget» and "Consolidated Budget». According to Article 6 of the Budget Code of Ukraine (Law of Ukraine No. 2456-VI, 2010), "Consolidated Budget» is a set of budget indicators used to analyse and forecast the economic and social development of the state. The consolidated budget of Ukraine includes indicators of the State Budget of Ukraine, the Consolidated Budget of the Autonomous Republic of Crimea (ARC) and the consolidated budgets of oblasts, cities of Kyiv and Sevastopol. In addition:

- The consolidated budget of the ARC includes indicators of the budget of the ARC, the consolidated budgets of its rayons and the budgets of significant cities of the ARC;

- The consolidated oblast budget includes indicators of the regional budget, consolidated budgets of rayons, budgets of cities of regional significance and budgets of the amalgamated territorial communities of this region;

- The consolidated rayon budget includes indicators of the rayon budget, budgets of cities of district significance, settlement and village budgets of this rayon;

- The consolidated city budget with the district division includes indicators of the city budget and district budgets that are part of it. If other cities, settlements or villages are administratively subordinated to a city or district in the city, the consolidated budget of the city or district in the city includes indicators of the budgets of these cities, settlements and villages.

Thus, the Consolidated Budget includes budgets of all levels, namely all local and the national budget. The State Budget is the budget of the central authorities only.

Hence, hereinafter the term «State Budget» (in capital letters) will mean the budget of central authorities in Ukraine in accordance with the Budget Code, and «state budget» (in lower case) will be used as a general term that means the budget of any country or state as a socio-political institution.

The calculations shown in table 2 confirm the previous conclusions. Nominal revenues of the State Budget of Ukraine have increased by 4 times over the last 10 years, but the real revenue has not increased. If we take the calculations in US dollars as a basis, revenues are lower even than the 2009 crisis indicators. 
Table 2

Revenues of the State Budget of Ukraine from 2008 to 2019

\begin{tabular}{|c|c|c|c|c|c|}
\hline \multirow{2}{*}{ Year } & \multirow{2}{*}{$\begin{array}{c}\text { GDP, } \\
\text { million UAH }\end{array}$} & $\begin{array}{c}\text { nominal } \\
\text { million UAH }\end{array}$ & \% GDP & $\begin{array}{c}\text { adjusted } \\
\text { for inflation } \\
\text { to } 2007\end{array}$ & in USD \\
\hline 2008 & 948056 & 231686 & $24,4 \%$ & 189906 & 179992 \\
\hline 2009 & 913345 & 209700 & $23,0 \%$ & 153059 & 117228 \\
\hline 2010 & 1082569 & 240615 & $22,2 \%$ & 147459 & 136419 \\
\hline 2011 & 1316600 & 314617 & $23,9 \%$ & 168246 & 163160 \\
\hline 2012 & 1408889 & 346054 & $24,6 \%$ & 188834 & 175781 \\
\hline 2013 & 1454931 & 339180 & $23,3 \%$ & 184163 & 183310 \\
\hline 2014 & 1566728 & 357084 & $22,8 \%$ & 155231 & 131805 \\
\hline 2015 & 1979458 & 534695 & $27,0 \%$ & 162206 & 90615 \\
\hline 2016 & 2383182 & 616275 & $25,9 \%$ & 166330 & 93270 \\
\hline 2017 & 2982920 & 793265 & $26,6 \%$ & 188301 & 112154 \\
\hline 2018 & 3558706 & 928108 & $26,1 \%$ & 200647 & 129407 \\
\hline
\end{tabular}

Source: compiled by the author based on the data of State Statistics Service of Ukraine, National Bank of Ukraine, and Ministry of Finance of Ukraine

If we consider the hryvnia equivalent adjusted for inflation, then compared to 2008, 2012 and 2013, the revenues of the State Budget of Ukraine have not increased significantly. However, we should pay attention to one more aspect the fiscal rate, which also increased by almost $2 \%$, and if we take 2010 as a basis, then by $4 \%$. This is a significant increase due to the growing tax burden on the state (for example, «Military tax»). Some sources say that this could also be done by bringing part of the business out of the "shadow", but we are considering a relative indicator. In this case, the official GDP should grow. In 2018, Growth of $2 \%$ of GDP was 71.174 billion UAH. Thus, revenue growth was caused by an increase in the tax burden or fiscal interest. If we set the fiscal interest at the level of 2008, we obtain the following data (table 3).

The next aspect to focus on is the level of concentration of Ukraine's budget. The level of concentration will be understood as the share of the Consolidated Budget of Ukraine that is taken up by the State Budget. Accordingly, the rest (it can be called the level of decentralization of the budget) are revenues (and corresponding expenditures) of local budgets.

One of the main tasks of budget reform was to reduce the concentration of financial flows within the central budget (Vasylyk \& Pavliuk 2002). Local budgets were to receive more revenue and more power. 
Figure 2

Revenues of the State Budget of Ukraine from 2008 to 2019

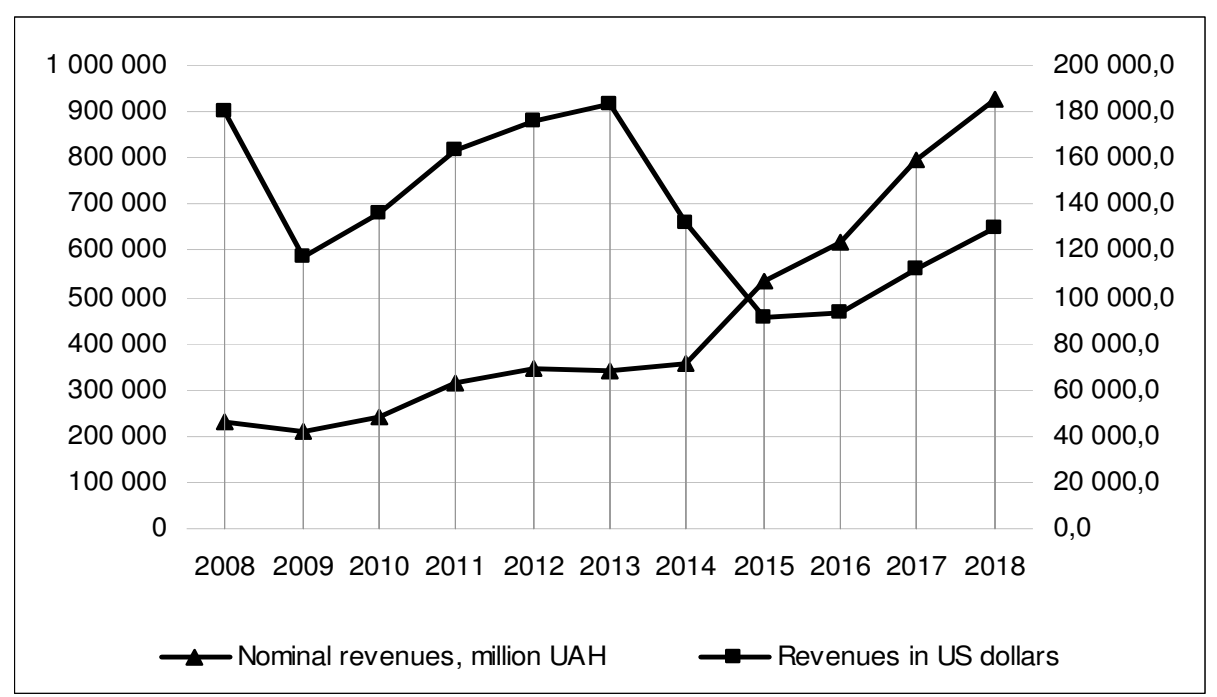

Source: created by the author based on the data of State Statistics Service of Ukraine, National Bank of Ukraine, and Ministry of Finance of Ukraine

Table 3

Revenues of the State Budget of Ukraine at a fixed fiscal interest rate in 2008

\begin{tabular}{|c|c|c|c|c|c|}
\hline \multirow{2}{*}{ Year } & \multirow{2}{*}{$\begin{array}{c}\text { GDP, mil- } \\
\text { lion UAH }\end{array}$} & $\begin{array}{c}\text { million } \\
\text { UAH }\end{array}$ & \% GDP & $\begin{array}{c}\text { adjusted for infla- } \\
\text { tion to 2007 }\end{array}$ & in USD \\
\hline 2008 & 948056 & 231686 & 24,4 & 189906 & 179992 \\
\hline 2009 & 913345 & 223204 & 24,4 & 162915 & 117228 \\
\hline 2010 & 1082569 & 264559 & 24,4 & 162132 & 136419 \\
\hline 2011 & 1316600 & 321751 & 24,4 & 172061 & 163160 \\
\hline 2012 & 1408889 & 344305 & 24,4 & 187880 & 175781 \\
\hline 2013 & 1454931 & 355557 & 24,4 & 193054 & 183310 \\
\hline 2014 & 1566728 & 382878 & 24,4 & 166444 & 131805 \\
\hline 2015 & 1979458 & 483741 & 24,4 & 146749 & 90615 \\
\hline 2016 & 2383182 & 582403 & 24,4 & 157188 & 93270 \\
\hline 2017 & 2982920 & 728967 & 24,4 & 173039 & 112154 \\
\hline 2018 & 3558706 & 869678 & 24,4 & 188015 & 129407 \\
\hline
\end{tabular}

Source: compiled by the author based on the data of State Statistics Service of Ukraine, National Bank of Ukraine, and Ministry of Finance of Ukraine 
Table 4

State and consolidated budget of Ukraine from 2011 to 2018 (nominal indicators in million UAH)

\begin{tabular}{|c|c|c|c|c|c|c|}
\hline \multirow{2}{*}{ Year } & \multicolumn{2}{|c|}{ State Budget } & \multicolumn{2}{c|}{ Consolidated Budget } & \multicolumn{2}{c|}{$\begin{array}{c}\text { Share of the State } \\
\text { Budget, \% }\end{array}$} \\
\cline { 2 - 7 } & Revenues & $\begin{array}{c}\text { Expendi- } \\
\text { tures }\end{array}$ & Revenues & $\begin{array}{c}\text { Expendi- } \\
\text { tures }\end{array}$ & Revenues & $\begin{array}{c}\text { Expendi- } \\
\text { tures }\end{array}$ \\
\hline 2011 & 314617 & 333460 & 398554 & 416854 & 78,9 & 80,0 \\
\hline 2012 & 346054 & 395682 & 445525 & 492455 & 77,7 & 80,3 \\
\hline 2013 & 339180 & 403403 & 442789 & 505844 & 76,6 & 79,7 \\
\hline 2014 & 357084 & 430218 & 456067 & 523126 & 78,3 & 82,2 \\
\hline 2015 & 534695 & 576911 & 652031 & 679871 & 82,0 & 84,9 \\
\hline 2016 & 616275 & 684743 & 782749 & 835590 & 78,7 & 81,9 \\
\hline 2017 & 793265 & 839244 & 1016788 & 1056760 & 78,0 & 79,4 \\
\hline 2018 & 928108 & 985842 & 1184278 & 1250174 & 78,4 & 78,9 \\
\hline
\end{tabular}

Source: compiled by the author based on the data of Ministry of Finance of Ukraine

As we see from the aforementioned data, in general, the distribution of financial resources between different levels of the budget system did not happen. The share of the State Budget of Ukraine or the level of concentration (excluding 2015) remained at 78-79 percent. Accordingly, the share of local budgets is about $21-22 \%$. Even if 2012 and 2013 are taken into account, the level of budget centralization has increased slightly. Thus, despite loud statements, the level of budget centralization in Ukraine is quite high.

There is a certain illusion that local budgets have received more money. If we take purely nominal indicators (table 5), then that is the truth. Nominally, local budget revenues increased compared to 2013 (we will continue to take this year as a starting point).

As we can see from the above data, the real total revenues of local governments did not increase compared to the base period. This confirms the previously stated judgments - GDP has not grown, so there is no financial basis. Often the literature and official reports of public authorities distort the data, and show a rapid increase in local budget revenues due to the reform (Fig. 3 and 4). Such data are published on the official website of the Ministry of Finance of Ukraine «Decentralization» portal, which is devoted to the problems of financial decentralization in Ukraine (Decentralization Project). 
Table 5

Total revenues of local budgets from 2013 to 2018 (million UAH)

\begin{tabular}{|c|c|c|c|c|c|}
\hline Year & Revenues & $\begin{array}{c}\text { Dollar } \\
\text { exchange rate }\end{array}$ & $\begin{array}{c}\text { Revenues } \\
\text { in dollars }\end{array}$ & $\begin{array}{c}\text { Inflation } \\
\text { index }\end{array}$ & $\begin{array}{c}\text { Inflation-adjusted } \\
\text { revenues }\end{array}$ \\
\hline 2013 & 103608 & 7,9 & 13115 & 100,5 & 103608 \\
\hline 2014 & 98983 & 11,9 & 8327 & 124,9 & 79250 \\
\hline 2015 & 117336 & 21,8 & 5371 & 143,3 & 65558 \\
\hline 2016 & 166474 & 25,6 & 6515 & 112,4 & 82751 \\
\hline 2017 & 223523 & 26,6 & 8404 & 113,7 & 97721 \\
\hline 2018 & 256170 & 27,5 & 9315 & 109,8 & 101998 \\
\hline
\end{tabular}

Source: compiled by the author based on the data of State Statistics Service of Ukraine, National Bank of Ukraine, and Ministry of Finance of Ukraine

Figure 3

Total revenues of local budgets from 2013 to 2018 (million UAH)

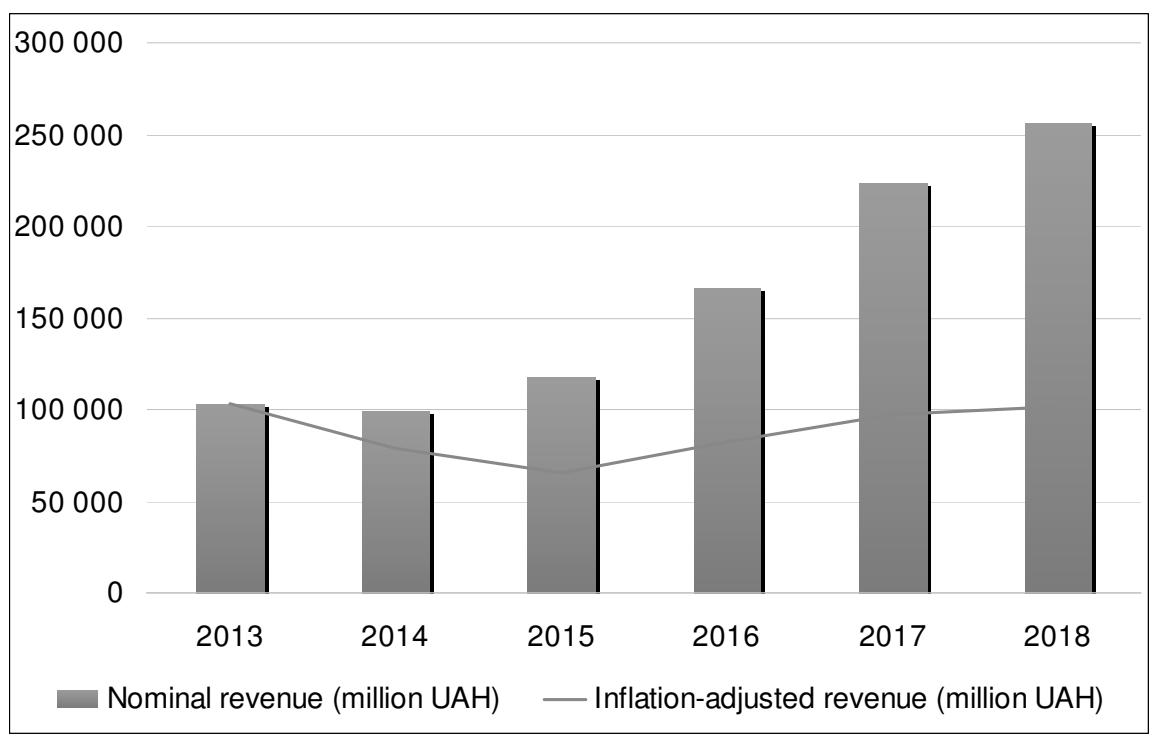

Source: created by the author based on the data of State Statistics Service of Ukraine, National Bank of Ukraine, and Ministry of Finance of Ukraine 
Figure 4

Own revenues of the general fund of local budgets, billion UAH

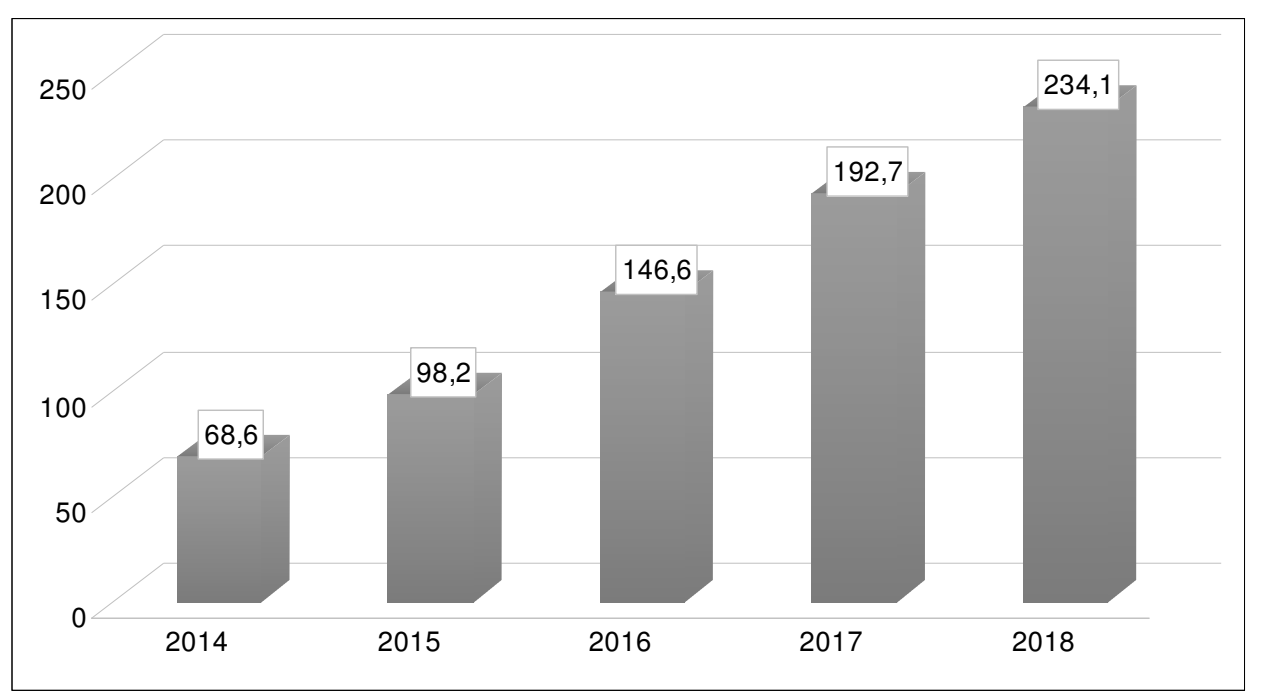

Source: created by the author based on the data of Open Budget Portal and Decentralization Project)

However, it should be understood that in accordance with the Law of Ukraine "On Voluntary Amalgamation of Territorial Communities» (Law of Ukraine No. 157-VIII, 2015), new administrative units began to be established in 2015, which now have their own budgets and funding mechanisms. In fact, that means that all local finances at this stage of development should be divided into two categories: existing administrative units and amalgamated territorial communities (ATCs). Over time, their number increases (for example, in 2017 the number of ATCs was 299, and in 2018 there were already 366), their budgets are taken into account under the new rules, and the share of existing administrative units decreases. In reality, there is a transfer of funds because while ATC budgets are growing rapidly, revenues of existing administrative units also rapidly declining. In general, local budgets did not receive more real (rather than nominal) funds.

Let us consider the structure of real revenues to local budgets for 20172018 in accordance with the new provisions of the Budget Code. 
Table 6

Structure of real revenues to local budgets for 2017-2018

\begin{tabular}{|l|c|c|c|c|}
\hline \multirow{2}{*}{ Tax } & \multicolumn{3}{|c|}{ ATCs' own revenues } \\
\cline { 2 - 5 } & \multicolumn{2}{|c|}{ (million UAH) } & \multicolumn{2}{c|}{$\%$ of total } \\
\cline { 2 - 5 } & 2017 & $\begin{array}{c}2018 \\
\text { months })\end{array}$ & 2017 & 2018 \\
\hline TOTAL & 11601 & 18866 & & \\
\hline Income tax & 4593 & 10521 & $40 \%$ & $56 \%$ \\
\hline Excise tax & 1396 & 1417 & $12 \%$ & $8 \%$ \\
\hline Land value tax & 2482 & 2756 & $21 \%$ & $15 \%$ \\
\hline Single corporate tax & 2477 & 3098 & $21 \%$ & $16 \%$ \\
\hline Property tax & 235 & 359 & $2 \%$ & $2 \%$ \\
\hline Other & 418 & 715 & $3,6 \%$ & $3,8 \%$ \\
\hline
\end{tabular}

Source: compiled by the author based on the data of Open Budget Portal and Decentralization Project)

Article 64 of the Budget Code of Ukraine (Law of Ukraine No. 2456-VI, 2010) «Structure of revenues of the general fund of budgets of cities of the republican significance of Autonomous Republic of Crimea and regional significance, cities of Kyiv and Sevastopol, rayon budgets, budgets of amalgamated territorial communities» identifies all possible sources of revenue to local budgets (excluding borrowings, transfers, donations, etc.). At present, the Budget Code lists 41 categories.

If we conduct an $\mathrm{ABC}$ analysis of local budget revenues, we can distinguish:

Group A - Individual income tax, which accounts for more than $56 \%$ of all revenues.

Group B - Single corporate tax, Land value tax, Excise tax, Property tax.

Group $\mathrm{C}$ - the other 36 sources.

Note that each tax (contribution, fee) requires certain administrative processes for the collection and control of funds. Each process has its cost and requires certain expenditures of both time and financial resources, which are covered from the same budget. In Article 4 of the Tax Code of Ukraine (Law of Ukraine No. 2755-VI, 2010) «Main principles of tax legislation of Ukraine», paragraph 4.1.7. highlights the principle of cost-effectiveness of taxation, which states that the establishment of taxes and fees should be conducted when the amount 
of revenue from their proceeds to the budget significantly exceeds the cost of their administration.

Thus, we can assume that almost all group $C$ sources are not economically justified. They only complicate tax and budget administration without having the necessary effect. Five sources are enough to fill local budgets, as they already account for $97 \%$ of revenues. As there are certain peculiarities in the formation of the revenue side of local budgets for specific communities, it may be necessary to add 3-4 other sources for balancing, such as inevitable fines and administrative penalties, payments (rent) from mining and use of natural resources that are located within the corresponding territory. However, in our opinion, the general list should not exceed 9-10 sources of budget revenues.

In order to exclude Group C due to its inefficiency completely, it would be enough, for example, to increase revenues from personal income tax by $7 \%$. There is no need to increase the tax rate to do this.

Note the following fact: individual income tax (56\%), excise tax (8\%) and single corporate tax $(16 \%)$, together give $80 \%$ of all revenues - these revenues directly depend on the level of business activity of economic entities registered in a particular territory. The amount of wages and the amount of the wage fund also, to some extent indirectly, depends on the level of business activity and development of economic entities.

The main disadvantage of the proposed concept of reforming budget relations is that local authorities have not received real effective mechanisms to influence the factor that shapes local budget revenues - business activity of economic entities. In fact, local authorities remain hostage to national policies and problems. They have very limited opportunities to develop their own territories.

According to numerous studies, there are several main obstacles to the development of domestic business, as well as the involvement of foreign businesses. They include the complexity of domestic legislation in all areas, especially tax, constant change of legislation («rules of the game»), corruption, lack of protection of property rights; lack of an impartial and fair legal system (courts, prosecutor's office, Ministry of Internal Affairs), lack of investment base, low level of infrastructure development, etc..

As an example, consider the indicator «time to prepare and pay taxes» - is the time (in hours per year) spent on the preparation, submission of documents and payment (or refusal to pay) of three main types of taxes: corporate income tax, value added tax or turnover tax, as well as labour taxes, including taxes from the payroll and contributions to social insurance funds. Figure 5 shows the World Bank data for several countries, including Ukraine. 
Figure 5

Time to prepare and pay taxes in different countries

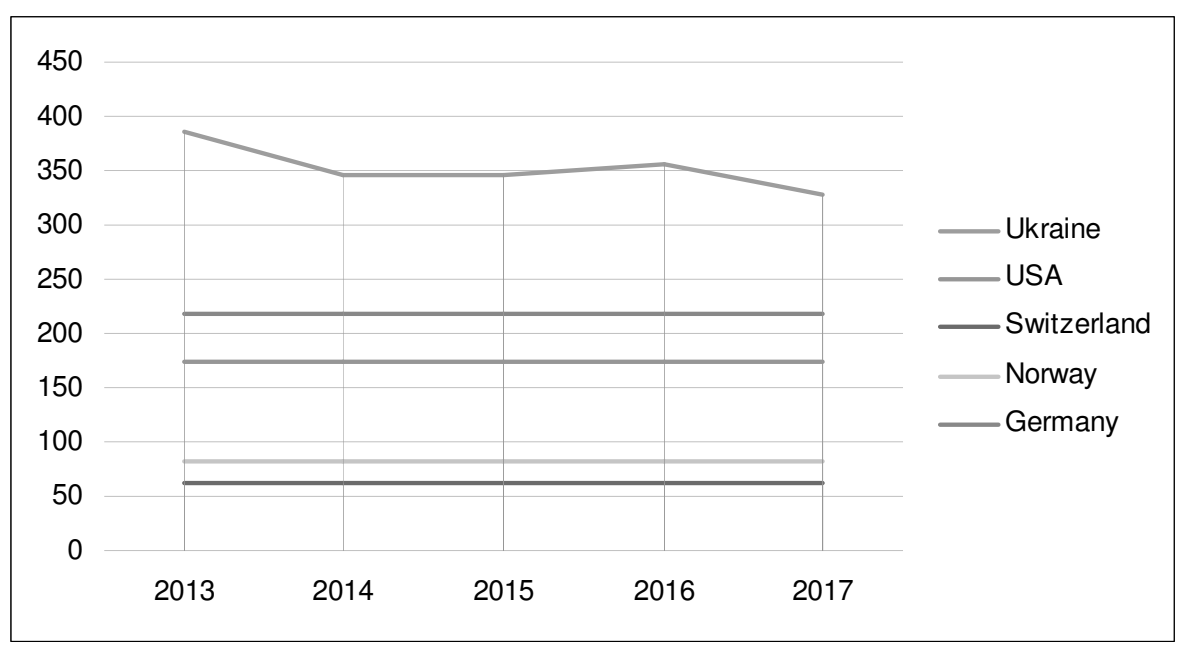

Source: created by the author based on the data of World Bank)

Figure 5 also illustrates the variability of domestic tax legislation. Each year, the time to prepare and pay taxes is different. In other countries, it is stable. This suggests that the tax legislation has not changed during this time.

The well-known belief that taxes in Ukraine are very high is not confirmed by numbers. In this respect, we are inferior to such developed countries as, for example, the United States or Japan, but the general tax pressure in Ukraine is lower than in many EU countries, especially in Scandinavia. The problem is quite different - tax legislation is so confusing, unstable and complex that it requires a lot of time and money. In recent years, Ukraine has been gradually improving its position in this aspect, for example, in 2008 this figure was 860 hours, in 2010 657, in $2012-488$, but all this is still far from world standards.

Thus, the time spent by the average entrepreneur to pay taxes is much higher than in developed countries. This is what hinders the development of entrepreneurship and the entry of foreign businesses into the Ukrainian market. In addition, the corruption component allows certain businesses to receive tax benefits that do not apply to others. It is almost impossible to compete fairly in such conditions.

All this greatly limits the business activity of economic entities and recently there has been a general decrease in their number. 
Table 7

Number of active enterprises in Ukraine

\begin{tabular}{|c|c|c|c|c|c|c|}
\hline & Number & \multicolumn{5}{|c|}{ including } \\
\cline { 3 - 7 } Year & $\begin{array}{c}\text { of active } \\
\text { Ukrain- } \\
\text { ian en- } \\
\text { terprises }\end{array}$ & $\begin{array}{c}\text { Wholesale } \\
\text { and retail } \\
\text { trade; repair } \\
\text { of motor ve- } \\
\text { hicles and } \\
\text { motorcycles }\end{array}$ & $\begin{array}{c}\text { Activities in } \\
\text { the field of } \\
\text { administra- } \\
\text { tive and } \\
\text { support ser- } \\
\text { vices }\end{array}$ & $\begin{array}{c}\text { Provision } \\
\text { of other } \\
\text { services }\end{array}$ & $\begin{array}{c}\text { Agricul- } \\
\text { ture, for- } \\
\text { estry and } \\
\text { fisheries }\end{array}$ & Industry \\
\hline 2013 & 669993 & 112243 & 53005 & 123240 & 50692 & 50298 \\
\hline 2014 & 631184 & 102345 & 48814 & 122547 & 48123 & 46445 \\
\hline 2015 & 624769 & 94770 & 50338 & 130919 & 47682 & 43409 \\
\hline 2016 & 605851 & 83120 & 58155 & 138156 & 45898 & 39554 \\
\hline 2017 & 640545 & 90861 & 62806 & 141121 & 50991 & 42836 \\
\hline 2018 & 666986 & 94732 & 66513 & 145823 & 51343 & 45355 \\
\hline $2018-2013$ & $\mathbf{- 3 0 0 7}$ & $\mathbf{- 1 7 5 1 1}$ & $\mathbf{1 3 5 0 8}$ & $\mathbf{2 2 5 8 3}$ & $\mathbf{6 5 1}$ & $\mathbf{- 4 9 4 3}$ \\
\hline
\end{tabular}

Source: compiled by the author based on the data of State Statistics Service of Ukraine)

Provision of other services - this section (as a residual category) includes the activities of public organizations, repair of computers, personal and household items, as well as a number of services that do not fall under the other classification.

Activities in the field of administrative and support services - renting, hire and leasing, employment activities, travel agencies, tour operators, other booking services and related activities, security services and investigations, maintenance of buildings and territories, administrative and ancillary office activities, other ancillary commercial services.

We can draw clear conclusions from the given data:

- the total number of enterprises did not increase compared to 2013 , but rather decreased;

- at the same time, the number of small enterprises in various branches of service has significantly increased;

- the number of industrial enterprises decreased by almost 5 thousand;

- the largest share of enterprises is occupied by trade and service enterprises, which either do not create real added value (trade) or have a small number of employees;

- the average size of enterprises is declining. 
The last two conclusions also confirm the data on employment and unemployment (table 8 last column).

Table 8

Main indicators of the labour market, 2010-2018

\begin{tabular}{|c|c|c|c|c|c|c|c|}
\hline \multirow[b]{3}{*}{ Year } & \multirow{2}{*}{\multicolumn{2}{|c|}{$\begin{array}{l}\text { Economically ac- } \\
\text { tive population of } \\
\text { working age }\end{array}$}} & \multicolumn{4}{|c|}{ including } & \multirow{3}{*}{$\begin{array}{l}\text { Average } \\
\text { number of } \\
\text { full-time } \\
\text { employ- } \\
\text { ees, } \\
\text { thousand } \\
\text { people }\end{array}$} \\
\hline & & & \multicolumn{2}{|c|}{$\begin{array}{l}\text { employed popula- } \\
\text { tion of working age }\end{array}$} & \multicolumn{2}{|c|}{$\begin{array}{l}\text { unemployed popula- } \\
\text { tion of working age }\end{array}$} & \\
\hline & $\begin{array}{c}\text { on aver- } \\
\text { age, } \\
\text { thousand } \\
\text { people }\end{array}$ & $\begin{array}{l}\% \text { of the } \\
\text { corre- } \\
\text { sponding } \\
\text { age } \\
\text { group }\end{array}$ & $\begin{array}{c}\text { on aver- } \\
\text { age, } \\
\text { thousand } \\
\text { people }\end{array}$ & $\begin{array}{l}\% \text { of the } \\
\text { popula- } \\
\text { tion }\end{array}$ & $\begin{array}{c}\text { on aver- } \\
\text { age, } \\
\text { thousand } \\
\text { people }\end{array}$ & $\begin{array}{l}\% \text { of eco- } \\
\text { nomically } \\
\text { active } \\
\text { population }\end{array}$ & \\
\hline 2010 & 19164,0 & 71,9 & 17451,5 & 65,5 & 1712,5 & 8,9 & 10262 \\
\hline 2011 & 19181,7 & 72,6 & 17520,8 & 66,3 & 1660,9 & 8,7 & 10083 \\
\hline 2012 & 19317,8 & 72,9 & 17728,6 & 66,9 & 1589,2 & 8,2 & 10123 \\
\hline 2013 & 19399,7 & 72,9 & 17889,4 & 67,3 & 1510,3 & 7,8 & 9720 \\
\hline 2014 & 19035,2 & 71,4 & 17188,1 & 64,5 & 1847,1 & 9,7 & 8959 \\
\hline 2015 & 17396,0 & 71,5 & 15742,0 & 64,7 & 1654,0 & 9,5 & 8065 \\
\hline 2016 & 17303,6 & 71,1 & 15626,1 & 64,2 & 1677,5 & 9,7 & 7868 \\
\hline 2017 & 17193,2 & 71,5 & 15495,9 & 64,5 & 1697,3 & 9,9 & 7679 \\
\hline 2018 & 17296,2 & 72,7 & 15718,6 & 66,1 & 1577,6 & 9,1 & 7661 \\
\hline
\end{tabular}

Source: compiled by the author based on the data of State Statistics Service of Ukraine)

The number of enterprises can be considered a relative indicator of the level of business activity. The unemployment rate is an absolute indicator (table 8). Despite the decrease of $0.8 \%$ over the last year, however, the unemployment rate remains very high and significantly exceeds the crisis figures of 20122013. Unemployment is unrealised GDP, a shortfall in wages, and as a result of shortfall for budgets at all levels and especially for local ones, which are more than half dependent on the wage funds of enterprises.

It should be noted that there has been a steady downward trend in the economically active population of working age, over the past 8 years it was almost 2 million people. Even as real average wages rise, real wages fund will remain at the same level or even decrease. This is a very big problem when filling local budgets. It can even be considered that this is the biggest threat to local budgets. 
Local authorities can influence only one of the above factors that hinder the development of domestic business, as well as the involvement of foreign businesses, but even this impact is only partial. Corruption can theoretically be overcome at the local level. However, everything else is in the scope of power of state authorities.

Based on the structure of local budget revenues, we determined that the best way of filling local budgets is to increase the business activity of economic entities as a whole, and increase the total real wage fund. Despite some limitations of management tools, local authorities can still stimulate certain processes. The ways of indirectly increasing individual income tax revenues can be as follows: increase gross regional product, which will increase the household incomes; increase the number of employed people by reducing unemployment; create new jobs; increase the size of the real average wages; increase capital expenditures from the budget, i.e. stimulation of local business through budget expenditures, etc.

However, it should be noted that achieving significant results at the local level will be almost impossible given the general negative business, investment and legal image of Ukraine.

To implement the above points, local authorities should be interested in working closely with entrepreneurs. By the way, these same ways of increasing the regional product will lead to an increase in revenues from the single corporate tax.

The composition and structure of gross regional product is one of the most important aspects of budget reform, the creation of ATCs and prospects for regional development. In other words, this means where and how added value is formed in the region (industry, enterprise size, form of ownership, etc.), as it is the basis for the formation of the wage fund. In this sense, the ATCs formed around the city-forming enterprise deserve the most attention. At the same time, it is necessary to highlight the ATCs, which are formed round the enterprises of the extractive industry (coal, iron ore). Such ATCs have or will have specific differences that bring them to the category of special. Such ATCs have or will have certain advantages and positive aspects, as well as face a number of threats.

First, as we see from the table, the average wage in the mining industry is much higher than in the industry in general (on average, wages in the mining industry are $20-30 \%$ higher). In turn, wages in industry are higher than the average in Ukraine. This suggests that potentially ATCs located, for example, in the eastern part of the Dnipro region (Pavlohrad district, Petropavlovsk district, etc.), near the city of Kryvyi Rih, Poltava region near Horishni Plavny, many districts of Donetsk and Luhansk regions would have higher revenues. 
Table 9

Average wages by type of economic activity in industry per month in 2018 (in UAH per one full-time employee)

\begin{tabular}{|l|c|c|c|c|}
\hline \multicolumn{1}{|c|}{ Type of economic activity } & $\begin{array}{c}1 \text { quar- } \\
\text { ter }\end{array}$ & $\begin{array}{c}2 \text { quar- } \\
\text { ter }\end{array}$ & $\begin{array}{c}3 \text { quar- } \\
\text { ter }\end{array}$ & $\begin{array}{c}4 \text { quar- } \\
\text { ter }\end{array}$ \\
\hline Average wages in Ukraine & 8382 & 9141 & 9042 & 10573 \\
\hline Industry & $\mathbf{9 2 7 4}$ & $\mathbf{9 5 5 2}$ & $\mathbf{9 8 1 7}$ & $\mathbf{1 1 5 6 3}$ \\
\hline Mining and quarrying & $\mathbf{1 1 7 3 5}$ & $\mathbf{1 2 3 9 8}$ & $\mathbf{1 2 8 7 0}$ & $\mathbf{1 4 1 6 0}$ \\
\hline including the extraction of coal and lignite & 11709 & 12004 & 12359 & 13127 \\
\hline $\begin{array}{l}\text { \% of the average wage of workers em- } \\
\text { ployed in the extractive industry }\end{array}$ & 127 & 130 & 131 & 122 \\
\hline Processing industry & 8816 & 9258 & 9474 & 10513 \\
\hline food, beverages and tobacco products & 7832 & 8315 & 8523 & 9270 \\
\hline $\begin{array}{l}\text { textile, clothing, leather, leather products } \\
\text { and other materials }\end{array}$ & 6487 & 6815 & 6959 & 7473 \\
\hline $\begin{array}{l}\text { wood products, paper production and } \\
\text { printing }\end{array}$ & 7861 & 8488 & 8466 & 9466 \\
\hline coke and refined petroleum products & 9073 & 11499 & 11398 & 12927 \\
\hline chemicals and chemical products & 8467 & 8714 & 8965 & 9560 \\
\hline $\begin{array}{l}\text { basic pharmaceutical products and } \\
\text { pharmaceuticals }\end{array}$ & 18097 & 17158 & 16389 & 18075 \\
\hline $\begin{array}{l}\text { rubber and plastic products; other non- } \\
\text { metallic mineral products }\end{array}$ & 8048 & 8612 & 8931 & 9762 \\
\hline $\begin{array}{l}\text { metallurgy, finished metal products, ex- } \\
\text { cept for machines and equipment }\end{array}$ & 11078 & 10915 & 11238 & 12496 \\
\hline $\begin{array}{l}\text { computers, electronic and optical prod- } \\
\text { ucts }\end{array}$ & 9881 & 10674 & 10719 & 14246 \\
\hline electrical equipment & 8056 & 8886 & 9162 & 9771 \\
\hline $\begin{array}{l}\text { motor vehicles, trailers and semi-trailers } \\
\text { and other vehicles }\end{array}$ & 9428 & 10283 & 10295 & 11855 \\
\hline $\begin{array}{l}\text { furniture, other products, repair and in- } \\
\text { stallation of machinery and equipment }\end{array}$ & 8257 & 8767 & 9345 & 10759 \\
\hline $\begin{array}{l}\text { supply of electricity, gas, steam and air } \\
\text { conditioning }\end{array}$ & 10684 & 10086 & 10440 & 15875 \\
\hline $\begin{array}{l}\text { water supply; sewerage, waste man- } \\
\text { agement }\end{array}$ & 6283 & 6418 & 6670 & 7585 \\
\hline
\end{tabular}

Source: calculated by the author based on the data of State Statistics Service of Ukraine) 
Second, in addition, the average statistical pensions would also be higher in these ATCs than in other settlements (including preferential ones).

Third, this means stability of employment and unemployment. As a rule, these large enterprises have a high demand for labour and provide stable employment for many years.

Such ATCs may even be the richest in terms of local budget revenues per capita. Thus, given the above, the purchasing power of the population would be higher, creating prospects for entrepreneurship once again through taxes to local budgets.

However, this is only the current situation. The prospects for the development of such ATCs are quite nightmarish. Along with this, there are significant problems with such ATCs.

1. According to statistics, problems of women's employment arise in connection with the mining specialization of the city. This, in turn, reduces the average income per family. In addition, as there are almost no other significant jobs, young people are trying to leave in search of prospects and a better life, so the demographic situation is far from good. As a result, these settlements, even quite large ones end up in negative ratings of depressed areas very often.

2. Problems of only one employer become problems of the whole ATCs. In fact, the community and the budget become hostages to the successful work of the city-forming enterprise without any prospects for changing such conditions. At one time in the 1990 s and early 2000 s, mining towns experienced all these problems.

3. This is the foremost problem. If we consider the general global trends, the mining industry (especially - coal mining) is one of the least promising sectors of the economy. Take the example of Germany, where one of the most important sectors of the German economy in the past has ceased to exist. December 21, 2018 will go down in German history as the day when the country's last coal mine, Prosper-Haniel, closed in the former mining town of Bottrop. Since then, coal is no longer mined in Germany. Only opencast lignite mining in quarries and sections has survived. The reason is very simple: coal is the energy source of the 19th and partly of the 20th, but not the 21st century. German miners had received subsidies of 200 billion euros, but the industry still ceased to exist. The "Coal Commission», created in the summer of 2018 by the German government, is actively working on a federal plan to completely abandon coal as the energy source most harmful to the global climate. One of the points of this plan will be closing several coal-fired power plants as soon as possible. The possible date is, for example, 2030. DeutscheBank has already stopped financing all and any coal-related programmes.

China has taken a different path. As the world's largest consumer of coal, it decided to extend the life of the coal industry and announced the completion of 

Strategy Development in Ukraine

a programme of environmental modernization of coal power. China now has the world's largest modern coal-fired energy sector. However, as in the case of Germany, such a path requires multibillion-dollar investments and strategies at the state level.

In general, the global energy structure is shifting away from the coal. It is increasingly being said that coal has no future. By 2045, the US state of California will switch completely to renewable electricity. The UK plans rich, which is in mining traditions, plans to close all coal-fired power plants by 2025, while the aforementioned China intends to reduce coal consumption after 2020. (World Bank).

In such circumstances, a global issue comes to the forefront - what should the development strategy of these areas be for example for the next 25 years? How should these areas be modernized? How to create development prospects and jobs for a new technological way of life? These problems are global and it is impossible to solve them at the level of one ATC. However, for the moment, the state has removed itself from the equation. These are strategic issues that only the state must address, and this solution will require over a decade-long targeted action and multibillion-dollar investments in the regions. Otherwise, ATCs will not be able to cope on their own and the state will face extremely difficult economic, political, social and demographic consequences. In fact, these ATCs will become completely dependent on the state budget and will only receive transfers from it. Demographic trends are already extremely complex at this stage, so over time, these settlements will simply cease to exist or remain a financial burden of the State Budget.

\section{Conclusions}

At the national level, the main goal of budget decentralization should be formulated as ensuring a more balanced territorial development and equalization of living standards throughout the country. This, initially, will stabilize migration, as well as social and demographic processes, and later lead to economic growth.

Creating effective local self-government, comfortable living conditions for citizens, and providing the latter with high quality and affordable public services should be the strategic task of modernizing the system of public administration and territorial structure of power.

The main condition for achieving these goals is the level of economic development of the respective territories, their financial condition and the adequacy of revenue sources of the local budgets. The financial aspect is one of the most important ones. The success of the operation of the amalgamated territorial communities depends upon it to a large extent. The presence of economically ac- 
tive business entities, a sufficient number of skilled workers, innovation, developed industrial and social infrastructure - all these are the basis for successful community development.

Based on this, in our opinion, the main result of the budget decentralization reform should be not the more efficient allocation and redistribution of community financial resources, as declared in programmes and projects, but higher selfmotivation and interest of local self-governments in increasing local budget revenues, searching for alternate funding sources, and improving the efficiency of tax and fee administration. Local self-governments must clearly understand the cause-and-effect relationship: the availability of sufficient resources in local budgets is a consequence of the level of economic activity in the region. However, at the state level, it is also necessary to provide local self-governments with effective governance mechanisms, not just to declare changes.

One of the main problems of Ukraine at this stage of development of budget decentralization reform is that the society has no effective mechanisms for influencing local self-governments and the decisions they make. The mechanism for allocating budget expenditures remains an instrument of political play and agitation. Budget decisions are not always made from the standpoint of socio-economic feasibility of a particular community.

\section{References}

1. Chuhunov, I., Ihnatenko, A. (2010). Personal income tax in the system of financial and economic regulation. Finance of Ukraine, No. 4, pp. 3-12.

2. Decentralization Project. Retrieved from: https://decentralization.gov.ua

3. Hordei, O., Patsaj, B. (2018). Priority directions of the financial support of the population's living standards in Ukraine. University Economic Bulletin, No. 36(1), pp. 275-285.

4. Law of Ukraine No. 1508-VII of June 17, 2014, On Cooperation of Territorial Communities. Retrieved from: https://zakon.rada.gov.ua/laws/show/1508-18

5. Law of Ukraine No. 157-VIII of February 5, 2015, On Voluntary Amalgamation of Territorial Communities. Retrieved from: https://zakon.rada.gov.ua/ laws/show/157-19

6. Law of Ukraine No. 2456-VI of July 8, 2010, Budget Code of Ukraine. Retrieved from: https://zakon.rada.gov.ua/laws/show/2456-17

7. Law of Ukraine No. 2755-VI of December 2, 2010, Tax Code of Ukraine. Retrieved from: https://zakon.rada.gov.ua/laws/show/2755-17 
8. Lunina, I. (2006). Public finance and reform of intergovernmental relations: a monograph. Project series "Naukova knyha», National Academy of Sciences of Ukraine, Institute of economics and forecasting, $432 \mathrm{p}$.

9. Lyutyy, I. (2009). Theoretical and methodological principles of state budget policy. Finance of Ukraine, No. 12, pp. 13-19.

10. Minfin Independent Financial Portal. Retrieved from: https://index.minfin.com.ua/

11. Ministry of Finance of Ukraine. Retrieved from: https://www.minfin.gov.ua/

12. Mochernyi, S., Larina, Ya., Plakhotniuk, O. (2005). The essence of finance in the context of economic relations. Finance of Ukraine, No 3, pp. 16-22.

13. National Bank of Ukraine. Retrieved from: https://bank.gov.ua/control/uk/ index

14. Ohon, Ts. (2006). Revenues of local budgets and directions of their restructuring. Finance of Ukraine, No. 1, pp. 3-9.

15. Oparin, V. (2005). Financial system of Ukraine (theoretical and methodological aspects): monograph. K.: KNEU, 239 p.

16. Open Budget Portal. Retrieved from: https://openbudget.in.ua/

17. Order of the Cabinet of Ministers of Ukraine No. 333-p of April 01, 2014, On approval of the Concept of Reforming Local Self-Government and Territorial Organization of Power in Ukraine. Retrieved from: https://zakon.rada.gov.ua/ laws/show/333-2014

18. Pikhotskyi, F., Kutsyk, M. (2018). State financial control in terms of fiscal decentralization policy. Business Inform, No. 11, pp. 375-379.

19. State Statistics Service of Ukraine. Retrieved from: - http://www.ukrstat.gov.ua/

20. Vasylyk, O., Pavliuk, K. (2002). Public Finance of Ukraine. K.: NIOS.

21. World Bank. World Development Indicators. Retrieved from: https://www.google.ru/ publicdata/directory

22. Yaroshenko, F., Bushuiev, S. (2011). Multi-vector management of public finance development programmes. Finance of Ukraine, No. 12, pp. 3-10.

23. Yuriy, S., Demianyshyn, V., Buzduhan, Ya. (2001). Anthology of the budgetary mechanism: monograph. Ternopil: Economic Thought, $250 \mathrm{p}$. 